\title{
DISCUSSION
}

\section{The design of diaphragm-type boundary total stress cells}

\author{
C. R. I. CLAYTON and A. V. D. BICA (1993). 43, No. 4, 523-535
}

\section{R. B. Meade, Geotechnical consultant, Vicksburg}

The experiments of the US Army Engineer Waterways Experiment Station (WES) (1944) and their further interpretation by Taylor (1947) provided the basis for the first criteria regarding cell compressibility. The Authors adapted a figure from the WES research to show that the criteria are not conservative because they omitted the compressibility of the soil. Important differences in cell design and experimental procedures limit the suitability of the comparison.

The Authors have interpreted the WES data on flush-mounted compressible cells in terms of diaphragm deflection. Taylor treated compression in a cell as if it were one-dimensional, i.e. the deformed shape of the cell remained cylindrical and only the thickness lessened. In fact, the WES experiments ensured that this was the case due to the design of the WES cell and through the measures taken to control the compressibility of the cell. These details are important and have bearing on the conclusions drawn by the Authors regarding cell compliance criteria.

The Authors state that the WES criterion was 'the ratio of the diameter of the diaphragm to the displacement of its centre $2 R / \delta$ should not be less than 1000'. Actually, the WES (1944) report did not use the term diaphragm. Rather it read, 'The change in the indicated pressures will be negligibly small if the ratio of the cell diameter to its deflection (compression normal to the pressure face) is greater than 1000 '.

The WES cells were composed of a face plate and a base plate that sandwiched a thin reservoir of oil between them. The base plate had a diaphragm created within it by boring, the face plate was in contact with the soil and the diaphragm in the base plate was in contact with the oil. As built, these cells were very stiff. The cells had to be modified so that compressibility could be studied. Compressibility was provided by springs added to the base plate of the cell. The springs were lock washers that formed single-turn helical springs. The compressibility of the springs was controlled by the length of the weld used to fix the springs to the base plate.

The cell compressed as the springs on the base plate reacted to the pressure on the face plate.
The face plate was much stiffer than the diaphragm within the cell and the cell translated from its original position at the face of the plaster used to form the rigid surface. The deflection was one-dimensional.

The one-dimensional compression created a stress field similar to the trap door problem. The WES compression was not a diaphragm action, whereas the compression in the Hall effect cell was diaphragm action. The WES study was intended to examine the effects on cell (body) compressibility, not diaphragm compressibility. Paragraph 8 of the appendix of WES (1944) noted, 'The two faces of the cell are parallel and compression is uniform, normal to the faces.'

In his analysis of the WES (1944) report Taylor (1947) determined that side friction in the apparatus reduced the pressure applied to the cells by $8 \%$. The Authors' tests were thought to have negligible side friction. The WES tests should have been adjusted for side friction before they were compared with the Authors' tests. The curve in Figs 1 and 15 should therefore have been moved up by $8 \%$.

\section{Authors' reply}

The description in the Paper of previous experimental work was too brief, and important details about the WES calibration tests (WES, 1944) were not given.

Paragraph 64 of WES (1944) states, 'Figure 12 indicates that all cells are roughly comparable, by using diameter-deflection ratio as a criterion. Although the data are scattered, the curve shows that for diameter-deflection ratios less than 1000 , indicated pressures decrease with the ratio, but for ratios greater than 1000 , indicated pressures remain essentially constant. The curve flattens out at a pressure ratio of $87.5 \%$, which is practically the same as the average pressure indicated by the four 3 in. flush-mounted control cells $(88 \%)$. The limiting permissible diameterdeflection ratio was found to be about 1000 . This means that a 3 in. cell could be allowed to compress a maximum of 0.03 in.* under the

* There is an error in WES (1944); the correct value is 0.003 in. 
maximum design pressure, and a 12 -in. cell could be allowed to compress a maximum of 0.012 in. under the maximum design pressure without altering appreciably the ratio of indicated to applied pressure.'

This clearly introduces a design criterion for the flush-mounted WES cell: the diameterdeflection ratio is required to be larger than 1000 . In so doing, a satisfactory cell action factor (CAF) is expected by the criterion, although the tcrm 'cell action factor'-often used nowadays--is not explicitly mentioned in WES (1944). This criterion was originally proposed solely for the flushmounted oil-filled WES cell. However, it has long been used for diaphragm-type boundary earth pressure cells as well (e.g. Trollope \& Lee, 1957). In the WES cell, the face plate deflection is thought to be nearly uniform across its diameter, with little diaphragm-type flexure deflection being superimposed. In the diaphragm-type cell, the diaphragm deflection has a concave shape across its diameter, with the maximum displacement at the centre. To adapt the WES criterion for diaphragm-type cells, the following equivalence rule has been used: the diameter-deflection ratio is replaced by the ratio between the diameter and the displacement at the centre of the diaphragm $2 R / \delta$, as shown by Trollope $\&$ Lee (1957). Other versions of the WES criterion (Kallstenius \& Bergau, 1956; Hanna, 1985) recommend a minimum $2 R / \delta$ of 2000 or even 10000 .

Our data, the WES data, and the data of Kallstenius \& Bergau are compared in Figs 1 and 15 in terms of CAF $\times 2 R / \delta$. In order to plot such different data together, $\delta$ means cell deflection, for the WES cell, and deflection at the centre of the diaphragm, for both our cell and the cell of Kallstenius \& Bergau. The main purpose of Fig. 1 is to show that - according to previous data-the cell action factor increases for increasing values of $2 R / \delta$. The main purpose of Fig. 15 is to show that-for a constant valuc of $2 R / \delta$ - the cell action factor decreases with increasing sand density, as shown by our preliminary calibration data using the Rowe cell. We then assumed that soil modulus was the missing parameter which could explain why the cell action factor varied so widely for the same value of $2 R / \delta$. This assumption was confirmed by further calibration tests which were performed in the triaxial equipment, following $K_{0}$ stress paths and using local strain measurement to allow accurate evaluation of soil modulus, as shown in Fig. 14. We finally concluded that fundamental design criteria for diaphragm-type boundary earth pressure cells must consider the relationship between soil stiffness and cell stiffness. The comparison of data in Fig. 15 therefore highlighted the fact that difficulties exist with current design methods for boundary earth pressure cells. Our subsequent calibration tests were designed to improve understanding of the behaviour of diaphragm-type cells.

According to WES (1944), all calibration tests of the WES cell were carried out using loose sand. The WES data, as plotted in Fig. 15, with $\delta$ meaning cell deflection, are roughly comparable with our data for loose sand, with $\delta$ meaning the displacement at the centre of the diaphragm. This is true whether the WES data are plotted in accordance with WES (1944) (i.e. without any correction for side friction) or in accordance with Taylor (1947) (i.e. with the average curve shifted upwards by a cell action factor of $8 \%$ to account for side friction). Other values could have been adopted in Fig. 15-within a reasonable rangefor the equivalence rule between cell deflection (for the WES cell) and diaphragm deflection (for the diaphragm-type cells) for the same data to be plotted together. For example, the displacement at the centre of the diaphragm could have been expressed in Fig. 15 by $\delta$ (for the diaphragm-lype cells), and the cell deflection (for the WES cell) could have been associated with a lower value, such as $\delta / 2 . \dagger$ The average curve of WES data would thus be moved to the right in Fig. 15. Even using this different equivalence rule, the replotted WES data remain roughly comparable with our data for loose sand. A theoretical equivalence rule may be difficult to establish for such different cell designs, due to non-linear effects. For example, for the case of piston-type cells, stresses tend to concentrate at the border of the cell when the soil modulus increases; the soil may subsequently yield, thus redistributing the stresses over the cell and changing the cell action factor. The establishment of a theoretical equivalence rule was outside the scope of the Paper. For the use we intended, the approximate equivalence rule mentioned appeared to be adequate.

If the WES cell had been calibrated with dense sand instead of loose sand, the cell action factor corresponding to each value of the diameterdeflection ratio would certainly be smaller, due to the consequently larger soil modulus. The average curve for dense sand would then plot below the average curve for loose sand (as shown in fig. 12 of WES (1944)), and the consequent limiting permissible diameter deflection ratio would certainly be larger than 1000 , to guarantee an adequate cell action factor. Some evidence sup-

$\dagger$ In other words, this equivalence rule assumes that a piston-type cell and a diaphragm-type cell of the same diameter will show the same cell action factor if the piston deflection at the design pressure is equal to half of the deflection at the centre of the diaphragm (for the diaphragm-type cell), at the same design pressure. 
porting this scenario can be taken from the elastic finite element analysis of a piston-type boundary earth pressure cell described by Carder (1976). For the same piston deflection (which was uniform across the cell diameter, and therefore similar to the WES cell), the larger the value of soil modulus assumed in the analysis, the smaller was the cell action factor. Weiler \& Kulhawy (1982) recommended that the diameter-deflection ratio should be larger than 20000 for piston-type cells.

We believe that improved design criteria for piston-type boundary earth pressure cells must consider soil modulus and suggest that calibration tests of piston-type boundary earth pressure cells be carried out to establish such design criteria. These tests should be performed in the triaxial equipment (to avoid side friction problems) with local strain devices, so that an accurate evaluation of soil modulus can be made. The Paper shows that $K_{0}$ stress paths should be followed in such calibration tests.

Our experience suggest that design criteria for boundary earth pressure cells based solely on cell stiffness are of historical significance. Nowadays, soil modulus can be determined more accurately than in the past and so design criteria based on the relationship between cell stiffness and soil stiffness are to be preferred.

\section{REFERENCES}

Carder, D. R. (1976). Finite element analysis of the performance of rigid plate soil pressure cells. Ground Engng 9, No. 8, 40-41, 46.

Hanna, T. H. (1985). Field instrumentation in geotechnical engineers. Series on rock and soil mechanics, vol. 10. Clausthall-Zellerfeld: Trans. Tech.

Kallstenius, T. \& Bergau, W. (1956). Investigation of soil pressure by means of cells. Proc. R. Swed. Geotech. Inst., No. 12.

Taylor, D. W. (1947). Pressure distribution theories, earth pressure cell investigations and pressure distribution data. Vicksburg: US Army Engineer Waterways Experiment Station.

Trollope, D. H. and Lee, I. K. (1957). The performance of a laboratory earth pressure cell. Aust. J. Appl. Sci. 8, No. 2, 84-97.

US Army Engineer Waterways Experiment Station (1944). Soil pressure cell investigation. Technical Memorandum 210-1. Vicksburg: USAWES.

Weiler, W. A. \& Kulhawy, F. H. (1982). Factors affecting stress cell measurements in soil. J. Geotech. Engng Div. Am. Soc. Civ. Engrs 108, GT12, 1259 1548. 